\title{
Pathomorphological evaluation of toxic effect of cypermethrin and cyphenothrin in common carp
}

\author{
Gözde YÜCEL, İbrahim Ayhan ÖZKUL
}

Ankara University, Faculty of Veterinary Medicine, Department of Pathology, Ankara, Turkey.

\begin{abstract}
Summary: In this study, juvenile common carp (Cyprinus carpio) were subjected to sublethal concentrations of the synthetic pyrethroids cypermethrin $(2 \mu \mathrm{g} / \mathrm{L})$ and cyphenothrin $(5 \mu \mathrm{g} / \mathrm{L})$ for 75 days. The toxic effects of these substances were analyzed pathomorphologically by conducting necropsies on 7 fish on days $15,30,45,60$, and 75 . In addition, histopathological examination of the gonads was performed by exposing to $17 \beta$-estradiol (E2) $(25 \mu \mathrm{g} / \mathrm{L})$ as a positive control group to assess the endocrine disrupting effects of cypermethrin and cyphenothrin. Hyperemia, telangiectasia, epithelial lifting, and branchitis were observed in the gills of the fish from both treatment groups, and hemorrhage in the kidneys and hyperemia in the brain were also detected. Only 1 fish from each of the cypermethrin and E2 groups was observed to have degeneration of the testicles and edema of the ovary. One fish from the cyphenothrin group had degeneration of the testicles and another had oophoritis of the ovary. Based on the hyperemia and telangiectasia observed in the gills, it was concluded that both cypermethrin and cyphenothrin may lead to shortness of breath in these fish. However, only minor lesions were detected in the gonads; thus, there was no evidence that these synthetic pyrethroids affect the endocrine system.
\end{abstract}

Keywords: Cypermethrin, cyphenothrin, Cyprinus carpio (common carp), 17ß-estradiol (E2), histopathology.

\section{Cypermethrin ve cyphenothrinin sazan balıklarına toksik etkisinin patomorfolojik yönden değerlendirilmesi}

Özet: Bu çalışmada, sentetik piretroitlerden olan cypermethrin ve cyphenothrinin belirlenen sublethal dozları $(2 \mu \mathrm{g} / \mathrm{L}$ ve 5 $\mu \mathrm{g} / \mathrm{L}$ ) juvenil sazan (Cyprinus carpio) balıklarına 75 gün süreyle uygulandı. Her gruptan yedişer balığın nekropsileri 15, 30, 45, 60 ve 75. günlerde yapılarak toksik etkileri patomorfolojik yönden değerlendirildi. Cypermethrin ve cyphenothrinin endokrin sisteme olan etkilerini değerlendirmek amaciyla pozitif kontrol olarak 17ß-estradiol (E2) $(25 \mu \mathrm{g} / \mathrm{L})$ verilerek gonadlar da histopatolojik yönden incelendi. Cypermethrin ve cyphenothrin grubuna ait balıkların solungaçlarında hiperemi, telangiektazi, epitelde ayrılma ve branşitis ile karşılaşıldı. Böbreklerde kanama ve beyinde hiperemi dikkati çekti. Gonadlarda ise cypermethrin ve E2 grubuna ait sadece birer balıkta testiste dejenerasyon ve birer balıkta ovaryumda ödem ile karşılaşıldı. Cyphenothrin grubuna ait bir balıkta ovaryumda ooforitis, bir balıkta ise testiste dejenerasyon görüldü. Solungaçlarda oluşan hiperemi ve telangiektazi bulguları birlikte değerlendirildiğinde; cypermethrin ve cyphenothrinin balıklarda solunum yetmezliğine yol açabilecekleri sonucuna varıldı. Bu çalı̧̧mada, gonadlarda az sayıda lezyon görülmesi nedeniyle sentetik piretroitlerin endokrin sisteme olan etkileri saptanmadı.

Anahtar sözcükler: Cypermethrin, cyphenothrin, Cyprinus carpio (sazan), 17ß-estradiol (E2), histopatoloji.

\section{Introduction}

Pesticides are toxic substances that are used to kill vermin or "pests." These formulations are designed to prevent, control, or diminish the destructive effects of these harmful organisms. Where pesticides are used accidentally or excessively, they can leave residues in the environment. When used continuously, they accumulate exponentially in the environment, plants, and other living organisms $(2,5,7,10)$.

Pyrethroids, synthetic analogs of the natural pyrethrins extracted from Chrysanthemum cinerariaefolium, are used in pesticides. Cypermethrin [CAS No. 52315-
07-8, cyano- (3-phenoxyphenyl) methyl-3- (2,2dichloroethenyl)-2,2-dimethylcyclopropane-1-carboxylate] is a synthetic pyrethroid that is commonly used as a pesticide (particularly against insects) to improve plant health and is also used as an ectoparasitic medication for animals (16). Cyphenothrin [CAS No. 39515-40-7, cyano (3-phenoxyphenyl) methyl 2,2-dimethyl-3- (2methylprop-1-en-1-yl) cyclopropanecarboxylate] is another synthetic pyrethroid that is commonly used against flies, mosquitoes, and cockroaches (15). Synthetic pyrethroids are considered safer than organophosphates, carbamates, and organochlorine

\footnotetext{
* This study was prepared from $\mathrm{PhD}$ thesis of the first author.
} 
compounds due to their lower persistence in the environment. However, pyrethroids have also been reported as being extremely toxic to aquatic organisms $(2,10)$.

Freshwater and marine animals are commonly used to analyze the ecotoxicology of chemical substances that are suspected to leave residues. Fish are among the creatures that are used for such analyses (9). In fish, 17 $\beta$ estradiol (E2), one of the natural estrogens that is secreted by the ovaries, stimulates the liver to synthesize vitellogenin, a protein that promotes the ripening of eggs $(6,8,12,18)$. It is believed that chemical substances that are expected to have estrogenic impact stimulate the synthesis of vitellogenin in the liver, allowing its degenerative effects to be identified in the gonads (12, 18).

In this study, we investigated the toxic effects of synthetic pyrethroids on common carp (Cyprinus carpio) by exposing fish to sublethal concentrations of cypermethrin $(2 \mu \mathrm{g} / \mathrm{L})$ and cyphenothrin $(5 \mu \mathrm{g} / \mathrm{L})$ for 75 days. The tissues and organs of the fish were analyzed pathomorphologically by conducting necropsies on 7 fish on days $15,30,45,60$, and 75 , and the gonads were examined histopathologically by exposing to $17 \beta$ estradiol (E2) as a positive control group to determine the effects of these chemicals on the endocrine system.

\section{Materials and Methods}

Common carp $(n=140)$ were obtained from the Public Waterworks Administration Amasya Water Resources Research Institute Hatchery Station. The fish had an average length of $15.51 \mathrm{~cm}$ and an average weight of $69.63 \mathrm{~g}$. The experiment was performed in the Ankara University Faculty of Veterinary Medicine Department of Pathology Experimental Unit (Ethic No: 2010-60310).

The carp were placed in 20 experimental aquaria at a density of 7 fish/aquarium for 15 days before the start of the experiment to allow them to acclimatize. Each $125-\mathrm{L}$ aquarium was filled with $100 \mathrm{~L}$ of water, which was aerated constantly.

Technical grade cyphenothrin $(93.1 \%)$ and cypermethrin (93\%) were obtained from the Insecticide Testing Laboratory of Hacettepe University, Ankara, and technical grade 17ß-estradiol (E2) (98\%) was obtained commercially. Sublethal concentrations of cypermethrin, cyphenothrin and concentration of E2 were determined to be $2 \mu \mathrm{g} / \mathrm{L}, 5 \mu \mathrm{g} / \mathrm{L}$, and $25 \mu \mathrm{g} / \mathrm{L}$, respectively, according to pre-test results and the findings of previous studies. All chemicals were stored at $4^{\circ} \mathrm{C}$ and brought to room temperature before introduction to the experimental setup. Doses of the chemicals were applied at 2-day intervals to maintain the pesticide and E2 concentrations.

Seven fish from each experimental group were euthanized on days $15,30,45,60$, and 75 , followed by necropsies. Tissue samples were fixed in $10 \%$ buffered neutral formalin, processed routinely, and embedded in paraffin blocks. These blocks were then cut into 4-6 $\mu \mathrm{m}$ sections, which were stained with hematoxylin and eosin (HE) and examined under a light microscope.

\section{Results}

Behavioral changes: Fish belonging to the control, cypermethrin, and E2 groups all showed normal behavior throughout the test period. The only unusual behavior was exhibited by a single fish from the cyphenothrin group, which was observed to swirl while swimming on the first day of treatment.

Macroscopic findings: No significant macroscopic findings were identified in any of the groups.

Microscopic findings: Fish from the control group did not exhibit any histopathological changes in any of the tissues examined (Figures 1a, 2a, 3a, 4a, 4c). Similarly, fish exposed to cypermethrin and cyphenothrin did not exhibit any significant histopathological changes in the tissues of the skin, spleen, stomach, intestines, heart, and skeletal muscles.

Cypermethrin: In the gills, hyperemia was observed in the central venous sinus (Figure 1b), artery, and capillary lumen. Telangiectasia was evident in the capillaries of the secondary lamellae (Figure 1c); epithelial lifting was also observed in the secondary lamellae (Figure 1d). Hemorrhage was seen. Branchitis was indicated by the presence of lymphocytes and macrophages in the primary and secondary lamellae of the gills (Figure 1b). Passive hyperemia and hydropic degeneration were seen in the livers of a few fish, and hemorrhage was observed in the kidneys of some. In the brain, hyperemia and focal gliosis (Figure 2b) were observed. Table 1 presents the number of fish in the cypermethrin group showing microscopic changes on each day.

In the gonads, a fish appeared to experience interstitial edema in the ovary on day 60, whereas degeneration of the seminiferous tubules of testicle was observed in one other fish on day 15 and in 2 fish on day 45 .

Cyphenothrin: In the gills, hyperemia, telangiectasia, epithelial lifting, and branchitis were observed. Passive hyperemia and hydropic degeneration were also seen in the liver (Figure 3b), and some hemorrhage was observed in the kidneys of some fish. In the brain, hyperemia and focal gliosis were observed. Table 2 presents the number of fish in the cyphenothrin group showing microscopic changes on each day.

In the gonads, 1 female fish had oophoritis with infiltration of lymphocytes and macrophages in the interstitial area of the ovaries on day 30 (Figure 4b), whereas the lumens of the seminiferous tubules were dilated in 1 male fish on day 15 (Figure 4d). 


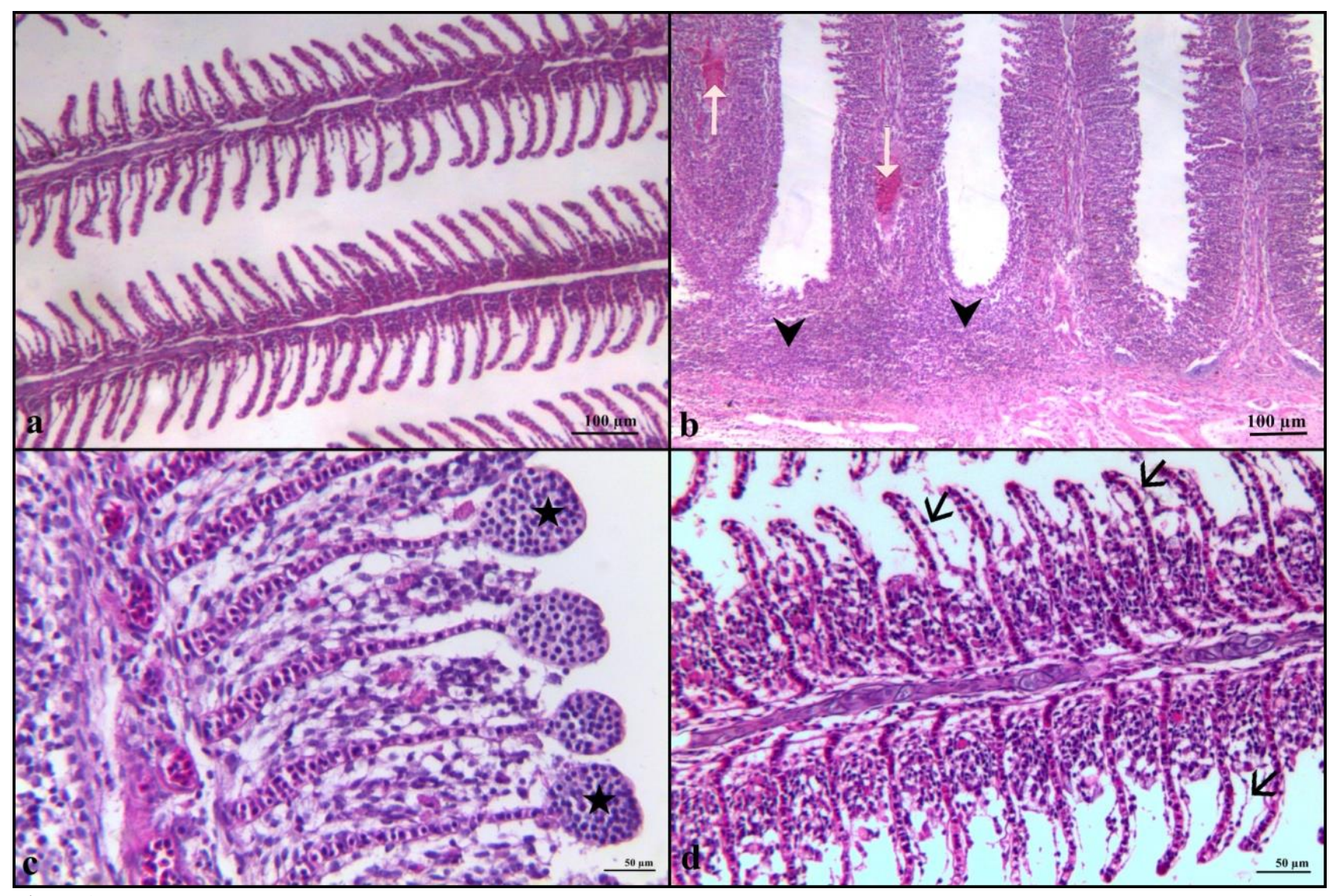

Figure 1.

a. Gill, control group, bar $=100 \mu \mathrm{m}$, HE.

b. Branchitis composed of mononuclear cells (arrow head), hyperemia in central venous sinus (white arrow), cypermethrin group, $45^{\text {th }}$ day, bar $=100 \mu \mathrm{m}$, HE.

c. Telangiectasia in the capillaries of the secondary lamellae (star), cypermethrin group, $15^{\text {th }}$ day, bar $=50 \mu \mathrm{m}, \mathrm{HE}$.

d. Epithelial lifting in the secondary lamellae (black arrow), cypermethrin group, $15^{\text {th }}$ day, bar $=50 \mu \mathrm{m}, \mathrm{HE}$.

Şekil 1.

a. Solungaç, kontrol grubu, bar $=100 \mu \mathrm{m}$, HE.

b. Mononüklear hücrelerin oluşturduğu branşitis (ok baş1), sentral venöz sinüsteki hiperemi (beyaz ok), cypermethrin grubu, 45 . gün, bar $=100 \mu \mathrm{m}, \mathrm{HE}$

c. Sekonder lamella kapillar lümenlerinde telangiektazi (yıldız), cypermethrin grubu, 15. gün, bar $=50 \mu \mathrm{m}$, HE.

d. Sekonder lamella epitellerinde ayrilma (siyah ok), cypermethrin grubu, 15. gün, bar $=50 \mu \mathrm{m}, \mathrm{HE}$.

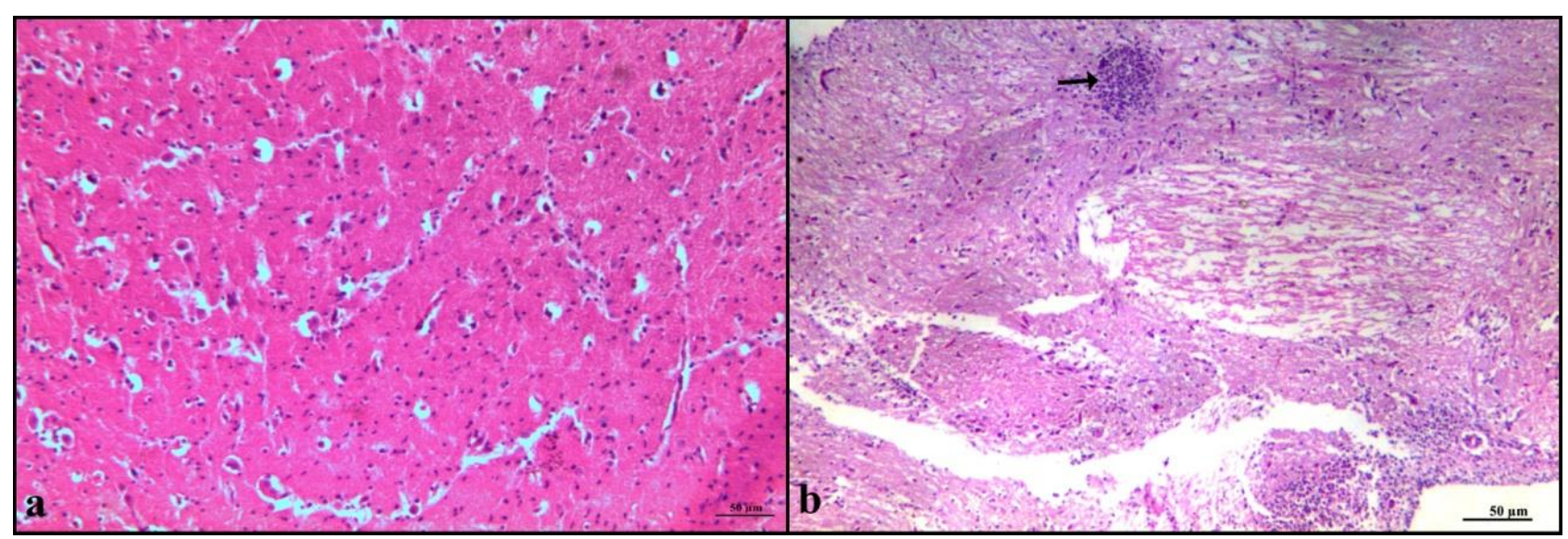

Figure 2.

a. Brain, control group, bar $=50 \mu \mathrm{m}, \mathrm{HE}$.

b. Focal gliosis (arrow), cypermethrin group, $45^{\text {th }}$ day, bar $=50 \mu \mathrm{m}, \mathrm{HE}$.

Sekil 2.

a. Beyin, kontrol grubu, bar $=50 \mu \mathrm{m}$, HE.

b. Fokal gliozis (ok) cypermethrin grubu, 45. gün, bar $=50 \mu \mathrm{m}$, HE. 


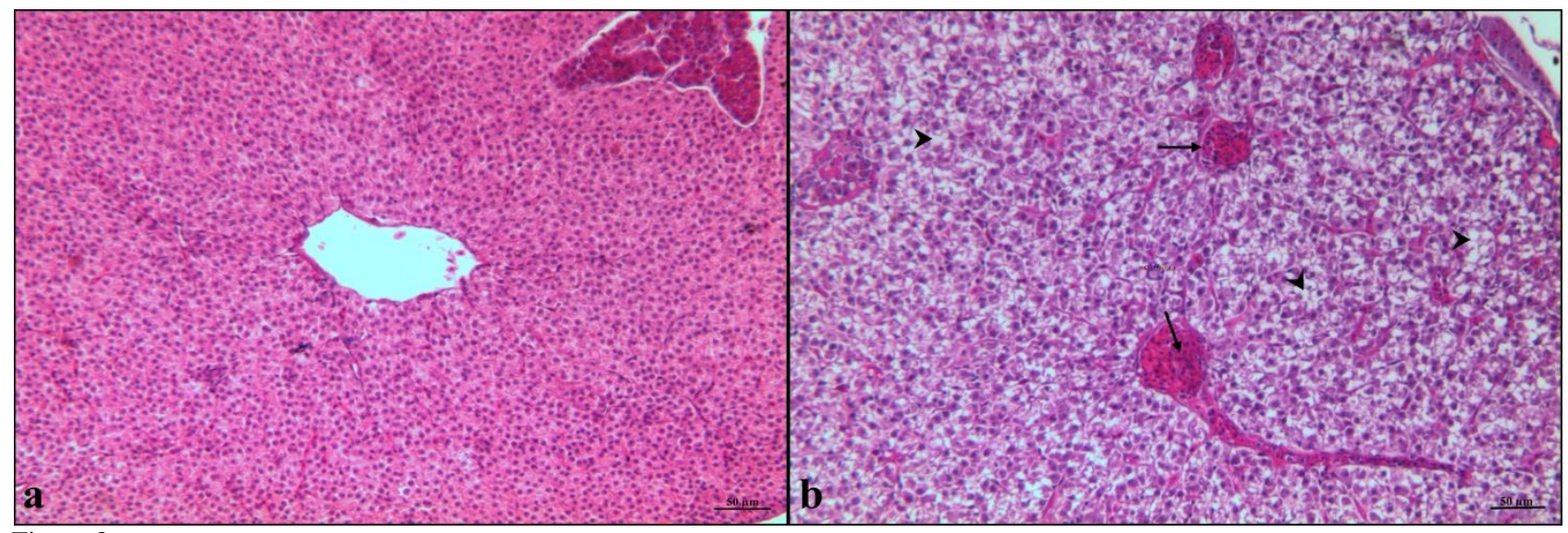

Figure 3.

a. Liver, control group, bar $=50 \mu \mathrm{m}, \mathrm{HE}$.

b. Hyperemia in central venous (arrow) and degeneration of hepatocytes (arrow head), cyphenothrin group, $15^{\text {th }}$ day, bar $=50 \mu \mathrm{m}, \mathrm{HE}$. Sekil 3.

a. Karaciğer, kontrol grubu, bar $=50 \mu \mathrm{m}$, HE.

b. Vena sentraliste hiperemi (ok) ve hepatositlerde dejenerasyon (ok başı) cyphenothrin grubu, 15. gün, bar $=50 \mu \mathrm{m}$, HE.

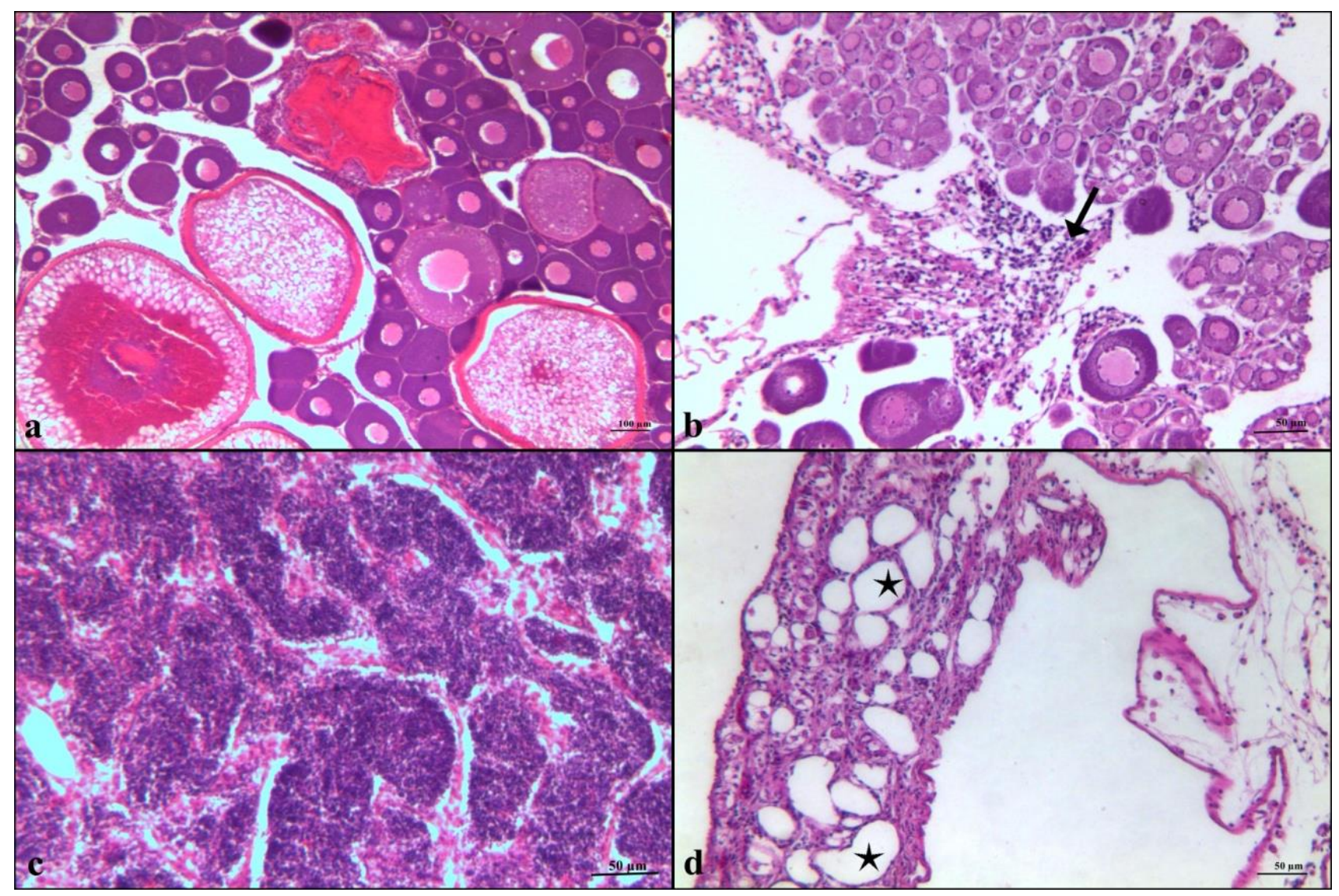

Figure 4.

a. Ovary, control group, bar $=100 \mu \mathrm{m}$, HE.

b. Oophoritis with infiltration of lymphocytes and macrophages in the interstitial area (arrow), cyphenothrin group, $30^{\text {th }}$ day, bar $=50$ $\mu \mathrm{m}, \mathrm{HE}$.

c. Testicle, control group, bar $=50 \mu \mathrm{m}$, HE.

d. Dilated lumens of seminiferous tubules (star), cyphenothrin group $15^{\text {th }}$ day, bar $=50 \mu \mathrm{m}, \mathrm{HE}$.

Şekil 4.

a. Ovaryum, kontrol grubu, bar $=100 \mu \mathrm{m}$, HE.

b. İnterstisyel bölgede lenfosit ve makrofajlardan oluşan ooforitis (ok), cyphenothrin grubu, 30. gün, bar $=50 \mu \mathrm{m}, \mathrm{HE}$.

c. Testis, kontrol grubu, bar $=50 \mu \mathrm{m}, \mathrm{HE}$.

d. Dilate seminifer tubul lumeni (yıldı), cyphenothrin grubu 15. gün, bar $=50 \mu \mathrm{m}$, HE. 
Table 1. The number of fish in the cypermethrin group showing microscopic changes on each day $(\mathrm{n}=7)$.

Tablo 1. Cypermethrin grubunda günlere göre mikroskobik bulgu görülen balık sayıları $(n=7)$.

\begin{tabular}{cccccc}
\hline Lesions & \multicolumn{5}{c}{ Groups $(\mathrm{n}=7)$} \\
& $15^{\text {th }}$ day & $30^{\text {th }}$ day & $45^{\text {th }}$ day & $60^{\text {th }}$ day & $75^{\text {th }}$ day \\
\hline Hyperemia in gill & 7 & 7 & 7 & 5 & 5 \\
Telangiectasia in gill & 3 & 0 & 0 & 0 & 0 \\
Epithelial lifting in gill & 4 & 7 & 5 & 7 & 7 \\
Hemorrhage in gill & 0 & 3 & 0 & 0 & 0 \\
Branchitis in gill & 7 & 3 & 3 & 0 & 0 \\
Passive hyperemia in liver & 1 & 1 & 0 & 0 & 0 \\
Dejenerasyon in liver & 0 & 0 & 0 & 0 & 1 \\
Hemorrhage in kidney & 2 & 2 & 1 & 0 & 0 \\
Hyperemia in brain & 2 & 2 & 3 & 6 & 6 \\
Gliosis in brain & 1 & 3 & 2 & 2 & 0 \\
\hline
\end{tabular}

Table 2. The number of fish in the cyphenothrin group showing microscopic changes on each day $(\mathrm{n}=7)$.

Tablo 2. Cyphenothrin grubu, günlere göre mikroskobik bulgu görülen balık sayıları $(n=7)$.

\begin{tabular}{cccccc}
\hline Lesions & \multicolumn{5}{c}{ Groups $(\mathrm{n}=7)$} \\
\hline $5^{\text {th }}$ day & $30^{\text {th }}$ day & $45^{\text {th }}$ day & $60^{\text {th }}$ day & $75^{\text {th }}$ day \\
\hline Hyperemia in gill & 7 & 4 & 7 & 4 & 7 \\
Telangiectasia in gill & 0 & 0 & 0 & 1 & 0 \\
Epithelial lifting in gill & 7 & 5 & 7 & 3 & 5 \\
Hemorrhage in gill & 0 & 0 & 0 & 0 & 0 \\
Branchitis in gill & 2 & 4 & 4 & 4 & 2 \\
Passive hyperemia in liver & 5 & 0 & 0 & 0 & 1 \\
Dejenerasyon in liver & 2 & 0 & 0 & 0 & 2 \\
Hemorrhage in kidney & 2 & 0 & 0 & 0 & 1 \\
Hyperemia in brain & 7 & 2 & 3 & 2 & 5 \\
Gliosis in brain & 1 & 0 & 1 & 1 & 1 \\
\hline
\end{tabular}

$17 \beta$-Estradiol (E2): Edema in the interstitial area was also detected in 1 female fish on day 45 . Degeneration was observed in the seminiferous tubules of 1 fish in this group on day 15 and in 1 of the 2 male fish on day 30 .

\section{Discussion and Conclusion}

Pesticides are often used in agriculture to kill pests, either to reduce their impact or to bring them under control. It is known that synthetic pyrethroids are safer for humans and other mammals than other pesticides. However, even when these compounds are used in small amounts, they can enter aquatic systems and be absorbed by fish, particularly freshwater fish that are consumed by humans. Therefore, in this study, we investigated the effects of these pesticides on common carp, as this sturdy fish is heavily consumed by people.

It has been widely reported that the effects of cyphenothrin and cypermethrin are mostly seen in the gills of fish $(4,3,11,14,17)$. In the present study, we found that both these substances may lead to shortness of breath in common carp, although the levels of hyperemia and telangiectasia in the gills were not consistent over the course of the study, with no linear increase or decrease with increasing exposure period. However, epithelial lifting as a result of swelling was detected in most fish in both treatment groups. Similar to the argument present by Lakani et al. (1) our study proves that epithelial lifting in the secondary lamellae functions as a defense mechanism by diminishing the interaction between the surface of the lamellae and the surroundings by increasing the diffusion barrier. Branchitis was observed in both treatment groups, but the incidence of this decreased through the course of the study in the cypermethrin group, possibly indicating that carp can tolerate this chemical over time.

Although cypermethrin and cyphenothrin were applied at sublethal doses, lesions were observed in the gills, as usually occurs with acute doses. This can be explained by the argument presented by Velisek et al. 
(13) that synthetic pyrethroids are strongly absorbed by the gills, even when present in only small amounts, due to their lipophilic nature.

We also observed passive hyperemia and degeneration in the liver, gliosis in the brain, and hemorrhage in the kidneys. However, these are not considered to be associated with exposure to pyrethroids as they were seen in few fish that had lesions.

Unfortunately, we were unable to determine the impact of cypermethrin and cyphenothrin on the endocrine system of carp by examining the gonads because the juveniles used in this study were not fully developed and their sex could not be determined accurately. However, the observation of degeneration and edema in some gonads indicates that additional research should be performed to evaluate the effect of these substances over a longer period of time on fish with fully developed gonads.

\section{Acknowledgements}

The authors thank Insecticide Testing Laboratory, Hacettepe University, Ankara, Turkey for a generous gift of $93.1 \%$ cyphenothrin and $93 \%$ cypermethrin used in the experiments.

\section{References}

1. Bagherzadeh Lakani F, Sattari M, Sharifpour I, et al. (2013): Effect of hypoxia, normoxia and hyperoxia conditions on gill histopathology in two weight group of beluga (Huso huso). Caspian J Env Sci, 11, 77-84.

2. Bradbury SP, Coats JR (1989): Comparative toxicology of the pyrethroid insecticides. Rev Environ Contam Toxicol, 108,133-77.

3. Dobsíková R, Velísek J, Wlasow T, et al. (2006): Effects of cypermethrin on some haematological, biochemical and histopathological parameters of common carp (Cyprinus carpio L.). Neuro Endocrinol Lett, 27, 100-105.

4. Erkmen B, Caliskan M, Yerli SV (2000): Histopathological effects of cyphenothrin on the gills of Lebistes reticulatus. Vet Hum Toxicol, 42, 5-7.

5. Geberding JL (2003): Relevance to Public Health. 14-18. In: Toxicological profile for pyrethrins and pyrethroids. Department of health and human services public health service agency for toxic substances and disease registry, Atlanta.

6. Hansen PD, Dizer H, Hock B, et al. (1998): Vitellogenina biomarker for endocrine disruptors. Trends Analyt. Chem, 17, 448-451.

7. Kaya S, Bilgili A (2002): Pestisidler. 385-536. In: S Kaya, İ Pirinçci, A Bilgili (Ed), Veteriner Hekimliğinde Toksikoloji. Medisan Press, Ankara.

8. Lange A, Katsu Y, Miyagawa S, et al. (2012): Comparative responsiveness to natural and synthetic estrogens of fish species commonly used in the laboratory and field monitoring. Aquat Toxicol, 109, 250-258.
9. OECD/OCDE (2011): OECD guideline for the testing of chemicals: Fish sexual development test. Retrieved Agust 17, 2014, from [http://www.oecdilibrary.org/docserver/download/9723401e.pdf?expires $=14$ 08304347\&id=id\&accname $=$ guest $\&$ checksum=BCB3953 E9608A8916814C8C490D7A32E].

10. Palmquist K, Salatas J, Fairbrother A (2012): Pyrethroid insecticides: Use, environmental fate, and ecotoxicology. 251-278. In: F Perveen (ed) Insecticides Advances in Integrated Pest Management. InTech Press, Croatia.

11. Sepici-Dinçel A, Cağlan Karasu Benli A, Selvi M, et al. (2009): Sublethal cyfluthrin toxicity to carp (Cyprinus carpio L.) fingerlings: Biochemical, hematological, histopathological alterations. Ecotoxicol Environ Saf, 72, 1433-1439.

12. Singh PB, Singh V (2008): Cypermethrin induced histological changes in gonadotrophic cells, liver, gonads, plasma levels of estradiol-17b and 11-ketotestosterone, and sperm motility in Heteropneustes fossilis (Bloch). Chemosphere, 72, 422-431.

13. Velisek J, Svobodova Z, Piackova, V (2009): Effects of acute exposure to bifenthrin on some haematological, biochemical and histopathological parameters of rainbow trout (Oncorhynchus mykiss). Veterinarni Medicina, 54, 131-137.

14. Velmurugan B, Mathews T, Cengiz EI (2009): Histopathological effects of cypermethrin on gill, liver and kidney of fresh water fish Clarias gariepinus (Burchell, 1822), and recovery after exposure. Environ Technol, 30, 1453-60.

15. WHO (2005): WHO specifications and evaluations for public health pesticides. Retrived Agust 17, 2014, from [http://www.who.int/whopes/quality/en/ddtranscyphenothrin_Spec_Eval_Sept_2005.pdf].

16. WHO (2012): WHO specifications and evaluations for public health pesticides. Retrived Agust 17, 2014, from [http://www.who.int/whopes/quality/en/Alphacypermethri n_WHO_specs_eval_Jan_2012.pdf].

17. Yildirim MZ, Benli AC, Selvi M, et al. (2006): Acute toxicity, behavioral changes, and histopathological effects of deltamethrin on tissues (gills, liver, brain, spleen, kidney, muscle, skin) of Nile Tilapia (Oreochromis niloticus L.) Fingerlings. Environ Toxicol, 21, 614-20.

18. Zaroogian G, Gardner G, Horowitz DB, et al. (2001): Effect of $17 \beta$-estradiol, o,p'-DDT, octylphenol and p,p'$D D E$ on gonadal development and liver and kidney pathology in juvenile male summer flounder (Paralichthys dentatus). Aquat Toxicol, 54, 101-112.

Geliş tarihi: 03.11.2015 / Kabul tarihi: 01.12.2015
Adress for correspondence:
Dr. Gözde YÜCEL
Ankara University, Faculty of Veterinary Medicine
Department of Pathology,
06110 Dışkapı/Ankara, Turkey.
e-mail:gozdeyucel@gmail.com 